Research Article

www.jestr.org

\title{
A Numerical Study on Response Modification Factor of CFS Walls Sheathed with Steel Sheets
}

\author{
S. Hatami ${ }^{1, *}$, M. Gholikhani ${ }^{1}$, F. Farahbod ${ }^{2}$ and M. R. Davani ${ }^{1}$ \\ ${ }^{I}$ Department of Civil Engineering, Yasouj University, Yasouj, Iran \\ ${ }^{2}$ Road, Housing and Urban Research Center (BHRC), Tehran, Iran
}

Received 7 July 2016; Accepted 12 April 2017

\begin{abstract}
In the recent years, steel sheet CFS shear wall has been used as a ductile lateral load bearing system for light steel frames. In this study, lateral behavior of this shear wall system is evaluated by finite element modelling of the frame, steel sheet and their connections. The lateral response of the reference wall has been compared to the available experimental data to validate the model. The extended models includes a wide range of the wall parameters such as wall height, steel sheet thickness, spacing of screws, and thickness of the frame members. Also, the influence of these properties of the walls on seismic response modification factor $(\mathrm{R})$ have been investigated. An equal energy concept considering post yielding energy absorption capacity is utilized to evaluate $\mathrm{R}$ factor and compare with those calculated according to Newmark and Hall method. This study also aims to realize the failure modes of the steel sheet CFS shear walls and suggest the methods to achieve an appropriate seismic performance. At the end, calculated $\mathrm{R}$ factors is compared to those prescribed values in the relevant codes.
\end{abstract}

Keywords: cold-formed steel, steel sheet, shear wall, R factor, seismic, finite element, numerical study

\section{Introduction}

In the recent years, cold-formed steel frames have been finding their way into the most conventional steel frames around the world. These kinds of frames are feasible, durable, light, and easy to work with.

For light weight steel structures, one of the lateral resistant systems is steel sheath cold-formed steel shear wall that has gained popularity among other lateral resistance systems because their construction facility, favorable seismic behavior such as high lateral resistance, and high ductility. Steel sheathed cold-formed steel (CFS) shear walls are identified amongst the lateral load resistant systems in ASCE07-10[1]. AISI S213-07[2] and recently AISI-S24015[3] and AISI- S400-15[4] present the nominal shear strength of steel sheathed CFS shear walls of 0.457 and $0.686 \mathrm{~mm}$ sheathing thicknesses with aspect ratios (i.e. height-to-width ratios) of up to $2: 1$ and $4: 1$,respectively.

However, these strengths are only given for a particular type of stud and tracks, aspect ratios, sheathing thickness and when the type of the wall element is altered these strengths are no longer useful.

Because of the complex behavior of wall panels, lateral resistant evaluation of shear wall has been carried out mainly by full scale experiments. In this vein the studies of Gad et

*E-mail address: hatami@yu.ac.ir

ISSN: $1791-2377$ @ 2017 Eastern Macedonia and Thrace Institute of Technology. All rights reserved. al.[5], Fulop and Dubina[6], Tian et al.[7], Serrette and Ogunfunmi[8], Kim et al.[9], Yu[10], Al-Kharat and Rogers[11], Hatami et al.[12], Zeynalian and Ronagh[13], Liu et al.[14], Javaheri-Tafti et al.[15], Mohebbi et al.[16] and Zeynalian and Ronagh[17] are of note. However, few studies have been carried out in the field of steel sheet CFS shear walls. Therefore, more detailed research is needed in order to better understand different aspects of the seismic performance of steel sheet CFS shear walls including estimation of the nominal shear strength capacity and the response modification factor, $\mathrm{R}$.

In this paper, a number of steel sheet CFS shear walls were modeled and numerically analyzed in ABAQUS software. The model investigate the effect of frame section thicknesses, thickness of sheathing sheet, wall height, sheathing material yield strength, screw spacing and connection details on the response modification factor $(\mathrm{R}$ Factor)of the walls. The obtained R Factors are compared with the offered values in related codes. Types of failure are evaluated, and the methods to improve the performance of these walls under lateral loading were suggested.

\section{Review of Literature and Code Provisions}

The first studies on the behavior of steel shear walls under lateral loading in cold-formed structures were carried out by Serrette et al. $[8,18]$. In this study, frames with two different structures were tested under two types of loadings as the 
monotonic and cyclic load and the shear strength of each wall were evaluated. They observed that the types of failure were different in each specimen. Generally, walls with large space between screws that connected the cover sheet to the frame failed due to the breaking of screws and the considerable deformation in sheathing. Serrette et al.[19] conducted cyclic tests on a wall with dimensions of $2.44 \times$ $1.22 \mathrm{~m}$ and with a sheet thickness of $0.686 \mathrm{~mm}$. Main failure mode of this wall was pulled out of the line of screws connecting the sheet to the frame.

Chang $\mathrm{Yu}[10]$ tested other types of shear walls and calculated the shear strength. In these tests, the focus was on using thicker steel sheets $(0.838,0.762$ and $0.686 \mathrm{~mm})$. The observed types of failure in these tests were similar to those in the tests conducted by Serrette et al. $[8,18]$.

In 2009, Chang Yu and Yu Ju Chen[20] evaluated lateral resistant of $1.83 \mathrm{~m}$ width walls by experimental data. This study included 19 steel shear wall specimens with 4 templates. The parameters considered in these studies included the effect of web depth, the thickness of frame member, the thickness of cover sheet, and the details of screws that connected the studs to the sheets. Test results indicated that in the walls with a width of $1.83 \mathrm{~m}$, sheet buckling and screw pull out are possible along with buckling of inner studs. They also realized that it is possible to use the nominal shear strengths tabulated by the code for these types of walls in a conservative manner. DaBreo et al.[21] and Balh et al.[22] tested a number of walls with various configurations at McGill University. The walls were differentiated by framing and sheathing thicknesses, screw fastener detailing, aspect ratio and framing reinforcement. They concluded that, in general, the use of closely spaced sheathing fasteners and thicker sheathing panels can lead to a higher shear resistance values. This is provided the stud members are designed to carry the increased shear resistance by means of blockings and the capacity based design approach. Yanagi and $\mathrm{Yu}[23]$ have presented the effective strip method, which is an analytical design method, for predicting the nominal strength of CFS shear wall panel. The proposed design approach shows good agreements with test results. The statistical assessment indicates that the new design method is reliable and provides designers an alternate tool to determine the strength of CFS shear wall panel without conducting full-scale shear wall tests. Javaheri-Tafti et al. [15] conducted an experimental investigation on cold formed steel frames sheathed by thin galvanized steel plates. The experiments involve 24 full-scale steel plated walls tested under cyclic loading with different configurations of studs and screws. The study also evaluates the failure modes of the systems. Design provisions of CFS shear wall panel require that the shear strength of shear walls with a height to width aspect ratio $(\mathrm{h} / \mathrm{w})$ greater than $2: 1$ be reduced by the factor $2 \mathrm{w} / \mathrm{h}$ for satisfying allowable story drift limit. The accuracy of this factor is investigated by Shakibanasab et al. [24] using the results of previous tests and the tests performed by the researcher. Results show that the reduction factor $(2 \mathrm{w} / \mathrm{h})$ is conservative. Thus, a relation is proposed for the reduction factor.

In the case of response modification factor of sheathed coldformed shear walls, particular detailed researches have been conducted. Blais [25] used an Equivalent Energy ElasticPlastic (EEEP) bilinear approach to evaluate the seismic parameters of over 180 single-story wood structural shear walls. In the end, ductility-related $\left(\mathrm{R}_{\mathrm{d}}\right)$ and over strengthrelated $\left(\mathrm{R}_{\mathrm{o}}\right)$ force modification factors were determined as 2.5 and 1.7 , respectively.
Rokas [26] utilizing an Equivalent Energy Elastic-Plastic (EEEP) bilinear model indicated that the specimens under monotonic loads have an average value of ductility-related force modification factors $\left(\mathrm{R}_{\mathrm{d}}\right)$ equal to 2.96 . In the case of reversed cyclic tests, calculated value was equal to 2.81 . The over strength-related force modification factor for all of the tests was determined equal to 1.79 .

Boudreault [27] conducted comprehensive tests on steel frame/wood panel shear walls under reversed cyclic tests. Results showed that an $R_{d}$ value of 2.5 and an $R_{o}$ value of 1.8 should be used for the walls with a maximum aspect ratio of $2: 1$.

Boudreault et al. [28] using an equivalent energy elasticplastic (EEEP) approach utilized the method based on the analysis of over 180 single-story shear wall/wood panel tests. In the end, the ductility $\left(R_{d}\right)$ and overstrength $\left(R_{o}\right)$ reduction factors were determined as 2.5 and 1.7 respectively.

Seismic response modification factor (R-factor) values for cold-formed steel buildings is provided in a number of codes including Uniform Building Code [29], International Building Code[30], FEMA 450[31], ASCE07-10[1], and NBCC[32].

ASCE07-10[1] obtains the response modification factor of 6.5 for Light steel frame (cold-formed steel) walls sheathed with wood structural panels rated for shear resistance or steel sheets.

The value of R-factor provided by UBC [29] is 5.5 for the buildings with less than three floors and walls sheathed with wood-based panels, and 4.5 for other types of walls. IBC [30] provides a value of reduction factor $\mathrm{R}$ (response modification coefficient) equal to 6.5 for the shear walls sheathed with wood panels or steel sheets, and 2 for other types of sheathings. Finally, R-factor equal to 6.5 is given by FEMA 450[31] for walls with shear panels.

\section{Seismic Response Modification Factor}

Despite the fact that the resistant design of buildings with no considerable damage in earthquake events is feasible, the elastic design of structures is usually not economical. Considering the inelastic behavior of structural components, buildings are designed for lateral load lower than its corresponding elastic value. Demand reductions from the elastic range to real inelastic demand are defined as reduction factors. This concept was first introduced by the Applied Technology Council in ATC-3-06[33] report as response modification factor ( $\mathrm{R}$ factor).

In this approach, while, all components that influence the lateral performance of structure should be able to experience excessive displacement beyond the elastic displacement range, a number of structural and/or nonstructural components are permitted to experience serious damages up to collapse. Of course, allowable damage in specific components must remain in the limited range so that it would not endanger global stability of structure. Also, appropriate arrangement of these components plays an essential role in achieving desirable performance of the structure.

Two major components including ductility reduction factor $\left(R_{d}\right)$ and structural over-strength factor $\left(\Omega_{0}\right)$ produce the response modification factor:

$R=R_{d} \times \Omega_{0}$ 
As Fig. 1 depicts, ductility reduction factor $\left(R_{d}\right)$ is defined as the ratio of the load response of elastic structure, $\mathrm{V}_{\mathrm{e}}$ to yielding point of inelastic structure, $\mathrm{V}_{\mathrm{y}}$.

$R_{d}=\frac{V_{e}}{V_{y}}$

Structural over-strength $\left(\Omega_{0}\right)$ is defined as ability of structure to resist beyond the design load:

$\Omega_{0}=\frac{V_{y}}{V_{S}}$

$\mathrm{V}_{\mathrm{s}}$ design force level is the first significant yield level of the structure, which corresponds to the force level beyond which the structure response starts to deviate significantly from the elastic response.

Fig. 1 indicates the general structural response and the method used to idealize a force-displacement curve based on ASCE 41-13[34]. The idealized bilinear curve is formed by two lines. The line segments shall be located by means of an iterative graphical method in order to balance the size of the areas of the idealized and actual curves. The initial secant stiffness is calculated through a base shear force equal to $60 \%$ of the idealized yield strength of the structure. The second segment line and the post-yield slope will be specified by a line which moves through the actual curve at the calculated target displacement, as $\Delta_{\mathrm{t}}$.

There is not a unique method to calculate target displacement. While some codes (ATC-3-06[33], ATC40[35]) prescribed different methods to evaluate target displacement, most

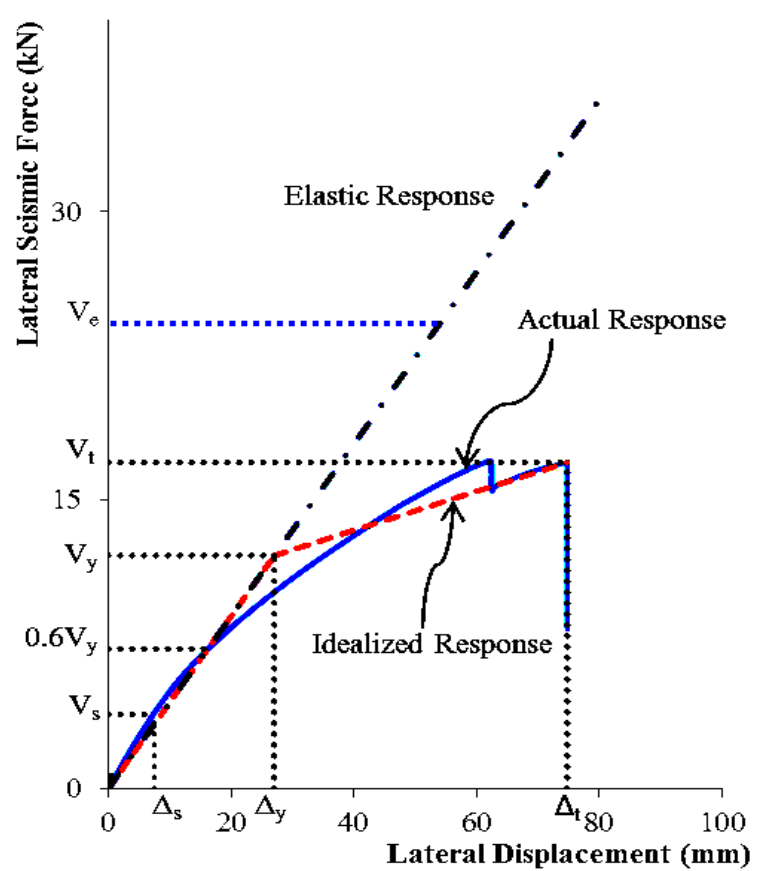

Fig. 1. General structural response of 2-8-43-33-4 specimen based on ASCE 41-13[34] concepts

Researchers prefer to use the maximum allowable displacement presented in seismic codes or displacement regarded to a special event. Park[36] defined maximum allowable displacement as one of the following definitions:

(a) The displacement corresponding to a particular limiting value of strain (b) The displacement corresponding to the peak point of load-displacement curve.

(c) Displacement corresponding to the post-peak displacement when the load carrying capacity has undergone a small redaction (for example, a $20 \%$ reduction in load)

(d) Displacement corresponding to abrupt fracture or buckling.

\section{Finite Element Modeling}

The consideration of all structural parameters in the lab costs a lot and it is time consuming. This study investigated the lateral behavior of cold-formed steel shear walls with the aid of ABAQUS finite element software. Application of the finite element method for the scrutiny of the structural and nonstructural performance of the buildings has become inevitable and commonplace in engineering departments. This method decreases duration of design and manufacturing as well as introduces a semi empirical approach.

One of the major failure modes of steel sheet CFS shear walls is the screws failure. If the screws are not considered in the modeling, the strength of the wall will be overestimated. In order to achieve better accuracy, the connecting screws are substituted with spring elements. By this method, it is possible to simulate connections failure and determine the displacements of the connection elements at the time of failure. The finite element model is verified by the existing experimental data.

\subsection{Geometric Specifications of the Models}

Each shear wall is composed of cold-formed steel sections and steel sheet connected to each other with Self Drilling screws. In the walls affected by monotonic loading, hold downs are installed on one side, where the loads are applied, to take the uplift force into account. In the present study, two types of frames of $0.61 \mathrm{~m} \times 2.44 \mathrm{~m}$ (Fig. $2 \mathrm{a}$ ) and $1.22 \mathrm{~m} \times 2.44 \mathrm{~m}$ (Fig. 2b) dimensions were investigated.

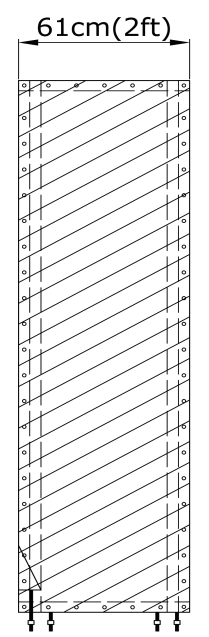

(a)

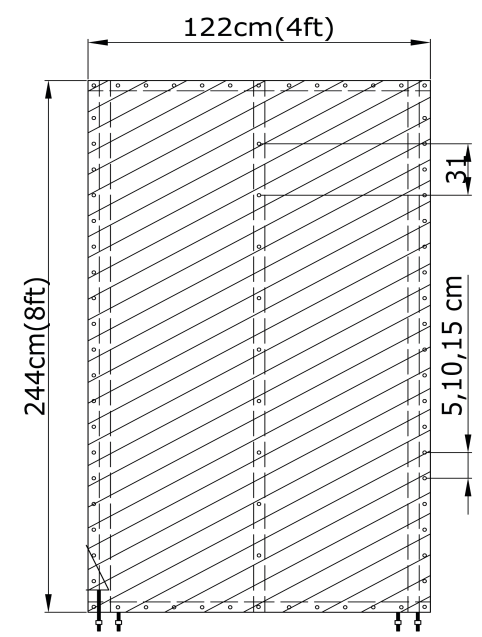

(b)
Fig. 2. General Configuration of specimens, $\mathrm{Yu}[10]$

All of the elements were constructed with the steel Gr. 33 according to ASTM A1003[37]. The studs are type $350 \mathrm{~S} 162$ and tracks are type 350T150 from SSMA Company[38]. The sections of studs and tracks are shown in 
Fig. 3 and their material properties are presented in Table 1. Stress- strain curve of materials used for ABAQUS modeling are shown in Fig. 4

Table 1. Mechanical Properties of the Frame Sections and Steel Sheathing

\begin{tabular}{l|l|l|l|l}
\hline $\begin{array}{l}\text { Elastic } \\
\text { modulus }\end{array}$ & $\begin{array}{l}\text { poisson's } \\
\text { ratio }\end{array}$ & $\begin{array}{l}\text { Yield } \\
\text { stress, } \\
\mathbf{F}_{\mathbf{y}}\end{array}$ & $\begin{array}{l}\text { Ultimate } \\
\text { stress, } \mathbf{F}_{\mathbf{u}}\end{array}$ & $\begin{array}{l}\text { Ultimate } \\
\text { strain, } \mathbf{e}_{\mathbf{u}}\end{array}$ \\
\hline 203.4 & 0.3 & $\begin{array}{l}227 \\
\mathrm{MPa}\end{array}$ & $310 \mathrm{MPa}$ & $\begin{array}{l}0.22 \\
(\mathrm{~mm} / \mathrm{mm})\end{array}$ \\
\hline $\mathrm{GPa}$ & & & \multicolumn{3}{|c}{} \\
\hline
\end{tabular}

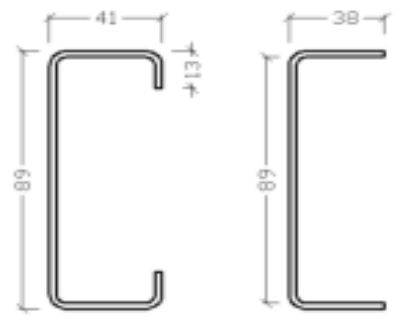

Track 350T150 Stud 350S162

Fig. 3. Detailed dimensions of stud and track (mm)

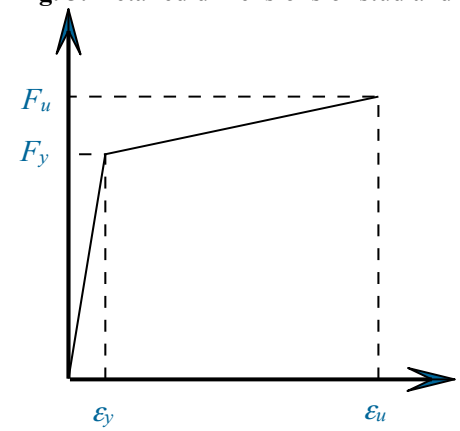

Fig.4. Stress-Strain curve using for finite element modeling

The boundary members (chord members) of a shear wall are typically constructed with a double section. The spacing of screws on the middle studs is equal to $31 \mathrm{~cm}$ in all of the specimens. However, their spacing around the perimeter (on the end studs and tracks) of the frame is different. The following spacing dimensions are used: 5,10 , and $15 \mathrm{~cm}$ (Fig. 2b).

\subsection{Boundary conditions and loading}

Light weight steel structures shear walls are typically installed on a concrete strip foundation. The lower tracks are connected to the foundation with anchor bolts. The upper tracks are also connected to the roof, which has a considerably higher stiffness than the track. For this reason, in laboratory experiments hot rolled beams were used to create the lower and upper supports of the wall.

In order to model this condition in ABAQUS software, the components of displacements $u_{x}, u_{y}, u_{z}$ are constrained at the lower points of the wall where the track is connected to the lower support. In order to model the boundary conditions of the hold down, Tie constraint is used at the point where hold downs are screwed to the stud. In ABAQUS, a Tie constraint provides a simple way to bond surfaces together permanently. Multi-point constraints (MPCs) are used to model the bolts connected to the ground. MPCs allow constraints to be imposed between different degrees of freedom of the model (Fig. 5a). In order to achieve the realistic boundary conditions, the movement of the wall in the $\mathrm{x}$ direction must be constrained. To this end, two supports are created at the top of the wall in the right and left directions and only the $u_{x}$ component is restrained.

Loading process is conducted using a displacement control procedure. MPC constraint is used for load application; the displacements of the connection screws are constrained to the point of load application (master node). The given displacement is applied to the reference node, and therefore the lateral displacement is uniformly exerted to all points of the upper track. In the pushover analysis, the entire upper track is under loading which results in lateral displacement of the shear wall.

\subsection{Element Type and Meshing}

ABAQUS has various elements including three dimensional elements, shell, beam, membrane, truss etc. to model different systems. In this research, shell elements are used to model the cold-formed sections. The 4-node S4R shell element with reduced integration was selected for the modeling of cold-formed steel frame and sheathing. This element has three translational and three rotational degrees of freedom at each node. The element accounts for finite membrane strains and arbitrarily large rotations. Therefore, it is suitable for large-strain analyses and geometrically nonlinear problems. Interaction analysis is performed to consider the frame-cover sheet interaction.

When a shear wall panel is analyzed, more organized meshing cause the analysis to converge in an improved manner and in shorter amount of time. In the contact analysis when a finer meshing is used for the slave material, the insertion of the sheet into the frame is inhibited. In the frame - cover sheet interaction analysis, the sheet is selected as the slave material. As a result, a finer mesh must be used at the point where the tracks and studs are connected. A sensitivity analysis study was conducted to select the optimized mesh size, which minimizes the analysis time while keeping the accuracy satisfactory. It was observed that on the areas without contact between sheathing and frame, on the cover sheet, square meshes with dimensions of $3.5 \mathrm{~cm}$ has the accurate result and in places with contact, triangular meshes with dimensions of $1 \mathrm{~cm}$ were deemed satisfactory (Fig. 5b). For stud and track triangular mesh with dimension equal to $3.5 \mathrm{~cm}$ was used.

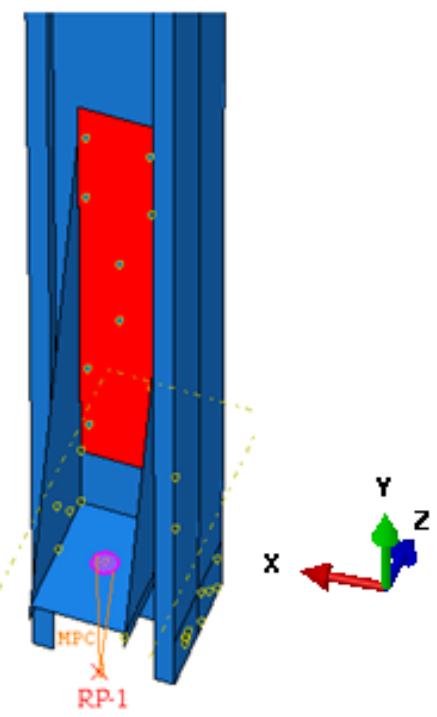

a) 


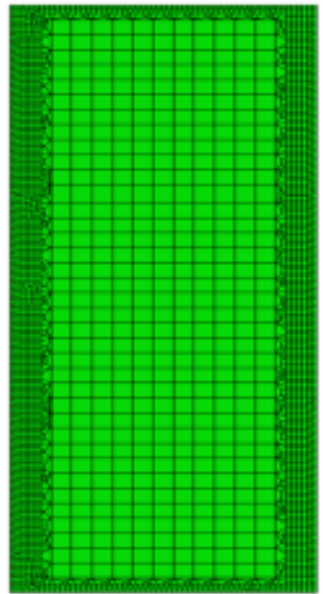

b)

Fig. 5. Modeling in ABAQUS: a) hold down b) mesh of cover sheet

\subsection{Modeling the screws and Frame-Shear Wall Interaction}

One of the predominant modes of failure in cold-formed steel shear walls is the pull out of connecting screws. Most perplexities during the modeling process of these shear wall panels are the detailed modeling of pull out of screws and tearing of the cover sheet that have an impact on the shear strength and deformation capacity. If such failures are not considered in the modeling, the strength of the wall may be overestimated. Therefore, the results of the model analysis will not represent the true behavior of the wall.

The connection screws are numerous and their modeling is tiresome. To achieve the realistic modeling of screw connection, several models were investigated and in the end the screws were substituted with the springs with elastic behavior up to failure at a certain force or displacement. With the elastic behavior of the spring, it is possible to model the loosening of the connection without any considerable convergence problem. Cartesian translational links (Fig. 6b) and Rotation rotational links (Fig. 6a) were used in order to model the Self-Drilling screws that connect the sheathing to studs and tracks.

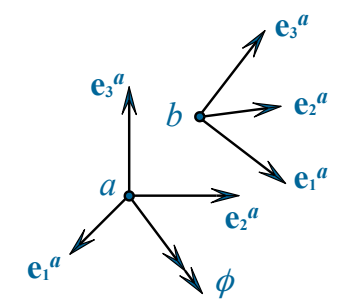

(a)

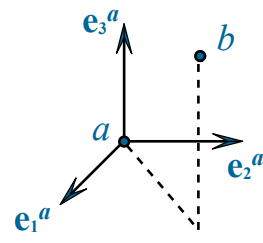

(b)
Fig. 6. Cartesian translational link and Rotation rotational link

The ultimate shear strength of the linear spring (elastic link) its stiffness are calculated so the finite element model has an acceptable compatibility to experimental result of the first three frames tested by $\mathrm{Yu}$ et al. [10,20]. Using this method, the shear strength, the stiffness and maximum deformation of the equivalent spring were considered as 5.1 $\mathrm{kN}, 6.5 \mathrm{kN} / \mathrm{cm}$ and $0.78 \mathrm{~cm}$, respectively.
Horizontal Frictional Contact of the frame and sheet cover have been designated to model the interaction of plate and frame by considering this assumption that two surfaces do not penetrate into each other and they may separate after the loading. Therefore the surfaces will not interlock and they will be able to slide on each other. After the cover sheet was buckled, the sheet may separate from the frame. In order to model the interaction of the sheet and the frame, a friction coefficient of 0.3 was used for horizontal contact.

\section{Verification of Finite Element Models}

The results of the finite element method were verified using the existing experimental studies conducted by $\mathrm{Yu}$ [39] and $\mathrm{Yu}$ and Chen[40]. 10 samples of shear walls with different properties including dimensions, thickness of frame sections, thickness of sheathing, and spacing of screws connection were compared and verified. The laboratory tests were performed such that two specimens were fabricated from each frame type and then they were tested. The acceptance criteria of the test results were a deviation in results should be less than 15 percent for the two specimens. In cases with differences of more than 15 percent in the lateral resistance of two specimens, a third specimen was tested. Dimensional modeling properties of 10 frames are presented in table 2 .

To assess the performance of the walls under monotonic loading, nonlinear pushover analysis was used. In order to provide the possibility of entering post-buckling behavior of members and cover sheet during the pushover analysis, it is necessary that an initial deformation (imperfection) be applied to the wall. To apply initial deformation, the linear buckling analysis is performed and the various modes of buckling of steel cover sheet and Studs are derived. Schafer and Pekoz[41] suggested that the thickness of the cover sheet be considered as the imperfection of studs. So, the calculated buckling modes are applied to the frames as initial deformation with maximum amount equal to the thickness of the cover sheet. Therefore, two distinct analyses need to evaluate the wall performance. In the first stage, a linear analysis was performed to extract the buckling mode of components. Then, with considering initial deformation, a nonlinear pushover analysis was performed.

Static nonlinear analysis has been conducted using displacement control method, in which the magnitude of the structural displacement is incrementally increased in accordance with a certain predefined pattern. With the increase in the magnitude of the displacement, weak elements and failure modes of the structure are found. Analyze were stopped when a significant decrease occur in lateral strength of shear wall. Maximum shearing force (lateral strength) and its corresponding displacement of the 10 walls were extracted from the finite element analysis. This data was compared with the experimental data in Table 3. In order to make an easier comparison between the experimental and finite element analysis results, the ratio of the strength and lateral displacement of the data calculated from the finite element analysis to the results of experimental analysis are also given. The average of the lateral resistance ratio is equal to 1.049 with a standard deviation of 0.0685 . These values show that the finite element method may predict the lateral resistance of coldformed steel shear walls with adequate accuracy. 
Table 2. Main dimensions of specimens (Yu[39], and $\mathrm{Yu}$ and $\mathrm{Chen[40])}$

\begin{tabular}{|c|c|c|c|c|c|}
\hline No & Specimen's name ${ }^{a}$ & $\begin{array}{c}\text { Frame dimension } \\
\text { Width (b) } \times \text { height } \\
(\mathbf{h}) \\
\mathrm{cm}(\mathrm{ft})\end{array}$ & $\begin{array}{c}\text { Cover sheet } \\
\text { thickness } \\
\left(t_{2}\right) \\
\text { mm (mil. inches) } \\
\end{array}$ & $\begin{array}{c}\text { Frame section thickness } \\
\qquad\left(t_{1}\right) \\
\text { mm (mil. inches) }\end{array}$ & $\begin{array}{c}\text { screws spacing } \\
\text { (s) } \\
\text { cm (inches) }\end{array}$ \\
\hline 1 & $2-8-43-33-6$ & $61 \times 244(2 \times 8)$ & 15.84 & 15.09 & 7.95 \\
\hline 2 & $2-8-43-33-4$ & $61 \times 244(2 \times 8)$ & 14.40 & & 6.27 \\
\hline 3 & $2-8-43-33-2$ & $61 \times 244(2 \times 8)$ & 17.07 & 17.04 & 6.68 \\
\hline 4 & $2-8-43-30-6$ & $61 \times 244(2 \times 8)$ & 17.32 & & 7.39 \\
\hline 5 & $2-8-43-30-4$ & $61 \times 244(2 \times 8)$ & 20.62 & 19.37 & 8.51 \\
\hline 6 & $2-8-43-30-2$ & $61 \times 244(2 \times 8)$ & 19.87 & & 7.75 \\
\hline 7 & $4-8-43-33-6$ & $122 \times 244(4 \times 8)$ & 12.98 & 13.98 & 8.38 \\
\hline 8 & $4-8-43-33-4$ & $122 \times 244(4 \times 8)$ & 13.26 & & 8.64 \\
\hline 9 & $4-8-43-33-2$ & $122 \times 244(4 \times 8)$ & 13.94 & 16.48 & 8.43 \\
\hline 10 & $2-8-33-27-2$ & $61 \times 244(2 \times 8)$ & 14.33 & & 8.25 \\
\hline
\end{tabular}

${ }^{\text {a }}$ Five part name is used for naming the frames; the parts indicate the width and height of the wall in feet, the thickness of the frame sections and cover sheet thickness in mil.-inches and the spacing of connecting screws in inches.

In case of the displacement corresponding to the maximum strength, according to table 4 , the results of finite element analysis do not fully follow the experimental results and they are markedly different in some cases. In this regard, two main reasons can be provided: First, in most of the walls tested by $\mathrm{Yu}[39]$, and $\mathrm{Yu}$ and $\mathrm{Chen[40],} \mathrm{due} \mathrm{to} \mathrm{the} \mathrm{variety} \mathrm{of}$ mechanisms that influence the displacement and ductility of the shear walls, the displacement of the two same samples differs significantly from each other. Second reason is that despite the fact that the failure of any screw connection has a major impact on convergence phenomenon, it has no significant impact on displacement. Experimental investigations show that the frames are able to reach more displacement range within maximum strength. Therefore, displacement range of finite element model is less than its prototype.

Fig. 7 shows load-lateral deflection curves of 2-8-43-334 specimen using the finite element method and its experimental result. This comparison shows that the finite element method can closely predict the load - deflection curve for a cold-formed steel shear wall. As it is shown in Figs. 8-10, the types of failure calculated by the finite element method and observed in the experimental specimens are compared for some different walls. Good agreement is seen for the types of failure between the two approaches. In case of the wall depicted in Fig. 8, the spacing of the screws that connect the cover sheet to the frame is $15 \mathrm{~cm}$. As can be seen in Fig. 8, shear buckling of the cover sheet and pull out of the connection screws are the major modes of failure. These failures are also observed in the finite element specimen. In the wall depicted in Fig. 9, the spacing of screws that connect the sheathing to the frame is $10 \mathrm{~cm}$. Although the type of failure is similar to the former wall (Fig. 8), pull out of screws occurred at a distance closer to the corner of the wall. This phenomenon is also seen in the finite element model. Fig. 10 indicates the type of failure for the wall with $1.22 \mathrm{~m}$ of width and with connecting screw spacing of $15 \mathrm{~cm}$.

Table 3.Comparison of finite element analysis date with experimental data from the references $(\mathrm{Yu}[39]$, and $\mathrm{Yu}$ and Chen[40])

\begin{tabular}{|c|c|c|c|c|c|c|c|c|}
\hline No & Specimen's name & $\begin{array}{l}\text { number of specimen } \\
\text { (experimental) }\end{array}$ & $\begin{array}{c}\mathrm{V}_{\text {max,Exp. }}{ }^{a} \\
(\mathrm{kN})\end{array}$ & $\begin{array}{c}\mathbf{V}_{\text {max,F.E. }}{ }^{b} \\
(\mathbf{k N})\end{array}$ & $\begin{array}{c}D_{\text {max,Exp. }}{ }^{c} \\
(\mathrm{~cm})\end{array}$ & $\begin{array}{c}D_{\max , F . E .}{ }^{d} \\
(\mathbf{c m})\end{array}$ & $\frac{V_{\text {max,F.E. }}}{V_{\text {max,Exp. }}}$ & $\begin{array}{l}D_{\text {max,F.E. }} \\
D_{\text {max,Exp }}\end{array}$ \\
\hline \multirow[t]{2}{*}{1} & \multirow[t]{2}{*}{$2-8-43-33-6$} & First & 15.84 & \multirow{2}{*}{15.09} & 7.95 & \multirow{2}{*}{6.65} & 0.95 & 0.84 \\
\hline & & Second & 14.40 & & 6.27 & & 1.05 & 1.06 \\
\hline \multirow[t]{2}{*}{2} & \multirow[t]{2}{*}{$2-8-43-33-4$} & First & 17.07 & \multirow{2}{*}{17.04} & 6.68 & \multirow{2}{*}{6.22} & 1.00 & 0.93 \\
\hline & & Second & 17.32 & & 7.39 & & 0.98 & 0.84 \\
\hline \multirow[t]{2}{*}{3} & \multirow[t]{2}{*}{$2-8-43-33-2$} & First & 20.62 & \multirow{2}{*}{19.37} & 8.51 & \multirow{2}{*}{6.75} & 0.94 & 0.79 \\
\hline & & Second & 19.87 & & 7.75 & & 0.98 & 0.87 \\
\hline \multirow[t]{2}{*}{4} & \multirow[t]{2}{*}{$2-8-43-30-6$} & First & 12.98 & \multirow{2}{*}{13.98} & 8.38 & \multirow{2}{*}{6.73} & 1.08 & 0.80 \\
\hline & & Second & 13.26 & & 8.64 & & 1.07 & 0.78 \\
\hline \multirow[t]{2}{*}{5} & \multirow[t]{2}{*}{$2-8-43-30-4$} & First & 13.94 & \multirow{2}{*}{16.48} & 8.43 & \multirow{2}{*}{7.40} & 1.18 & 0.88 \\
\hline & & Second & 14.33 & & 8.25 & & 1.15 & 0.90 \\
\hline \multirow[t]{2}{*}{6} & \multirow[t]{2}{*}{$2-8-43-30-2$} & First & 16.31 & \multirow{2}{*}{17.51} & 8.38 & \multirow{2}{*}{6.08} & 1.07 & 0.73 \\
\hline & & Second & 16.34 & & 8.71 & & 1.07 & 0.70 \\
\hline \multirow[t]{2}{*}{7} & \multirow[t]{2}{*}{$4-8-43-33-6$} & First & 15.22 & \multirow{2}{*}{15.56} & 5.28 & \multirow{2}{*}{3.18} & 1.02 & 0.60 \\
\hline & & Second & 16.73 & & 4.37 & & 0.93 & 0.73 \\
\hline \multirow[t]{2}{*}{8} & \multirow[t]{2}{*}{$4-8-43-33-4$} & First & 17.45 & \multirow{2}{*}{19.81} & 4.39 & \multirow{2}{*}{3.67} & 1.13 & 0.84 \\
\hline & & Second & 17.92 & & 5.89 & & 1.11 & 0.63 \\
\hline \multirow[t]{2}{*}{9} & $4-8-43-33-2$ & First & 19.60 & & 6.43 & & 1.10 & 0.53 \\
\hline & & Second & 20.48 & 21.62 & 4.19 & 3.42 & 1.05 & 0.82 \\
\hline 10 & $2-8-33-27-2$ & First $^{\mathrm{e}}$ & 12.87 & 13.92 & 5.46 & 6.30 & 1.08 & 1.15 \\
\hline & & & & & & & 1.049 & 0.81 \\
\hline & ard Deviation & & & & & & 0.0685 & 0.18 \\
\hline & $\begin{array}{l}\text { al strength of the ex } \\
\text { al strength of the fir } \\
\text { al displacement of } t \\
\text { al displacement of } t\end{array}$ & $\begin{array}{l}\text { mental specimen } \\
\text { element specimen } \\
\text { xperimental specimen } \\
\text { nite element specimen }\end{array}$ & & & & & & \\
\hline
\end{tabular}




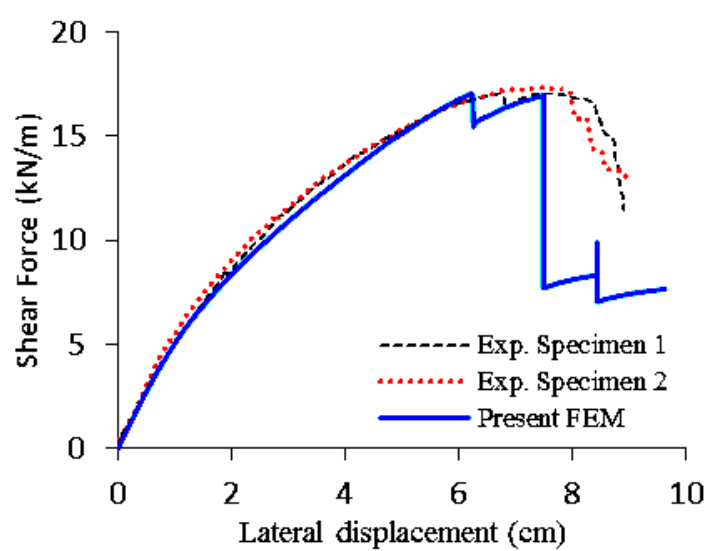

Fig. 7. Experimental and finite element analysis results of 2-8-43-33-4 specimen
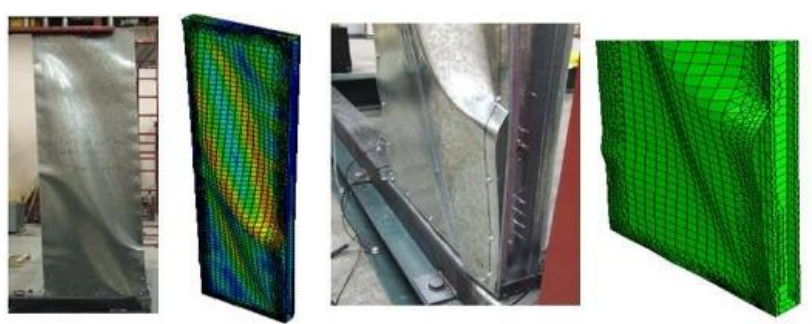

Fig. 8. Comparison of failure modes of the finite element model and the experimental specimens (Yu and Chen[40]) for wall 2-8-43-33-6

\section{Numerical Evaluation of R-Factor for the Walls}

With the aid of the finite element method it is possible to investigate seismic performance of different frames with various characteristics including the height of the wall, the thickness of cover sheet, the yield strength of wall sections, the thickness of frame sections, and the spacing of screws that connects steel sheet to frame. For this purpose, the main components of $\mathrm{R}$ factor presented in section 3 were evaluated using force-displacement curves resulted from pushover analysis. To this end, ASCE 41-13[34] method was used to form the idealized bilinear curve from envelope force-displacement curves. Then, requisite parameters are constructed from bilinear force-displacement curve.
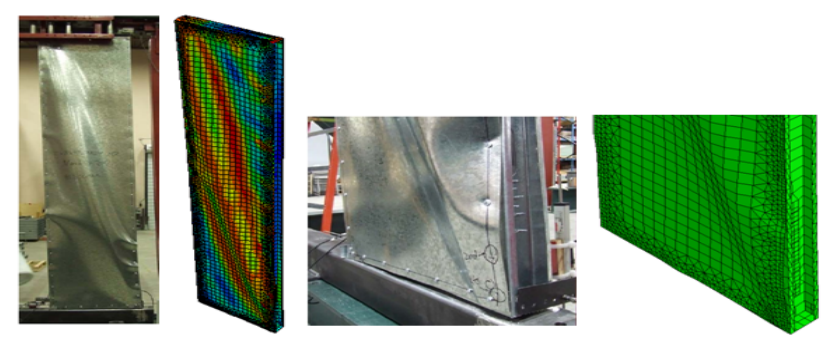

Fig. 9 Comparison of failure modes of the finite element model and the experimental specimens [40] for wall 2-8-43-33-4
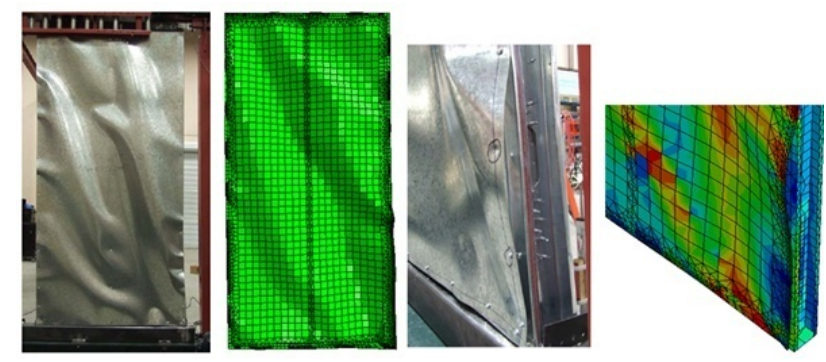

Fig. 10. Comparison of failure modes of the finite element model and the experimental specimens [40] for wall 4-8-43-33-6
In this study, the target displacement is considered as the maximum displacement before the significant decrease $(20 \%$ reduction) in the strength of the structure (see Fig. 1).

Based on Zeynalian et al. [42] research, two methods have been used to determine the ductility reduction factor:

(1)Calculating $R_{d}$ using Eq. (2): The equation requires the proportion of $\mathrm{V}_{\mathrm{e}}$ to $\mathrm{V}_{\mathrm{y}}$. For this purpose, the concept of equal energy has been used. As shown in Fig. (11), the area of the elastic response and the idealized response is assumed to be equal:

$R_{d}=\frac{V_{e}}{V_{y}}=\sqrt{\left(\frac{\Delta_{t}}{\Delta_{y}}-1\right)\left(\frac{V_{t}}{V_{y}}+1\right)+1}$

(2) Calculating $R_{d}$ using the Newmark and Hall [43] method: A set of equations in terms of $\mu$ for ductility reduction factor was developed by Newmark and Hall[43]. $\mu$ is defined as the proportion of target displacement, $\Delta_{t}$ to displacement of yielding point of ideal model, $\Delta_{\mathrm{y}}$ :

$\mu=\frac{\Delta_{\mathrm{t}}}{\Delta_{y}}$

Newmark and Hall[43]:

$$
\begin{array}{ll}
R_{d}=\mu & \mathrm{T}>0.5 \mathrm{~s} \\
R_{d}=\sqrt{2 \mu-1} & 0.1<\mathrm{T}<0.5 \mathrm{~s} \\
R_{d}=1 & \mathrm{~T}>0.1 \mathrm{~s}
\end{array}
$$

The concepts demonstrated in Fig. 12 are used to evaluate the first "significant yield" strength point. To this end, the curve's nodes which have drifts of up to $\% 10$ of the maximum shear wall's drift, $d_{c, \max }$, were considered as well as the drifts' deviations between the envelope curve and the linear trend-line were calculated using Eq. (8). The assumption was that the significant yield point is the point with a deviation smaller than $\% 0.5$. Then the corresponding lateral load is derived and recorded as $\mathrm{V}_{\mathrm{S}}$ :

$D_{i}=\frac{d_{L i}-d_{C i}}{d_{C, \max }}(\%)$

Where $D_{i}$ is the drifts' deviations associated with the $i^{\text {th }}$ point $\left(\mathrm{X}_{\mathrm{i}}\right) ; \mathrm{d}_{\mathrm{Li}}$ is the drift of linear trend-line associated to point $X_{i} ; d_{c i}$ is the drift of the envelope curve associated to point $X_{i}$; and $d_{c, \text { max }}$ is the Maximum shear wall's drift.

Two types of walls with heights of 244, 274, and $304 \mathrm{~cm}$ were modeled and analyzed. The first series were 2-h-43-332 specimens and the second series were 2-h-43-33-4 specimens that are different in screws spacing.

Table 4 indicates the ultimate loads and $\mathrm{R}$ factors of the walls with different heights. It is realized that higher walls possess lower lateral resistance. The only exception is for 
the 2-8-43-33-2 wall with a height of $274 \mathrm{~cm}(9 \mathrm{ft})$ that exhibits a lower lateral resistance compared to a wall with height of $304 \mathrm{~cm}(10 \mathrm{ft})$. This fact can be justified by the type of failure of the frame with a height of $274 \mathrm{~cm}$, which covers sheet buckling and distortional buckling of the corner stud near the hold down were the main mode of failure, whereas the $304 \mathrm{~cm}$ high frame was only experienced cover sheet buckling as the mode of failure. These types of failure were considered in the studies of $\mathrm{Yu}$ [10]. Therefore the resistance of the $304 \mathrm{~cm}$ high frame is higher than the 274 $\mathrm{cm}$ high fame.

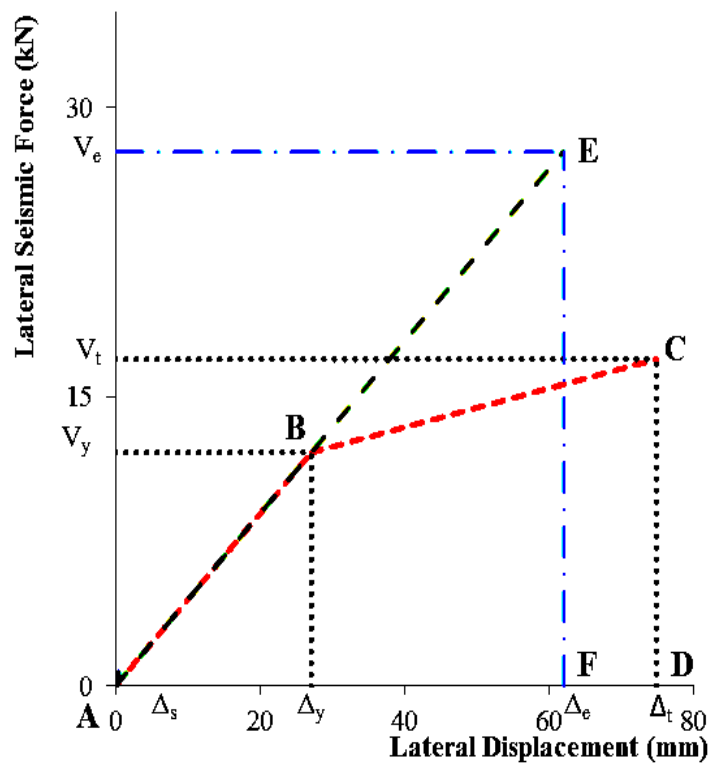

Fig. 11. Calculating $R_{d}$ using equal energy concept for 2-8-4333-4Specimen

Area $_{\mathrm{AEF}}=$ Area $_{\mathrm{ABCD}} \Rightarrow$

$$
\begin{aligned}
& R_{d}=\frac{V_{e}}{V_{y}}=\sqrt{\left(\frac{\Delta_{t}}{\Delta_{y}}-1\right)\left(\frac{V_{t}}{V_{y}}+1\right)+1}= \\
& =\sqrt{\left(\frac{74.79}{27.06}-1\right)\left(\frac{16.95}{12.11}+1\right)+1} \cong 2.29
\end{aligned}
$$

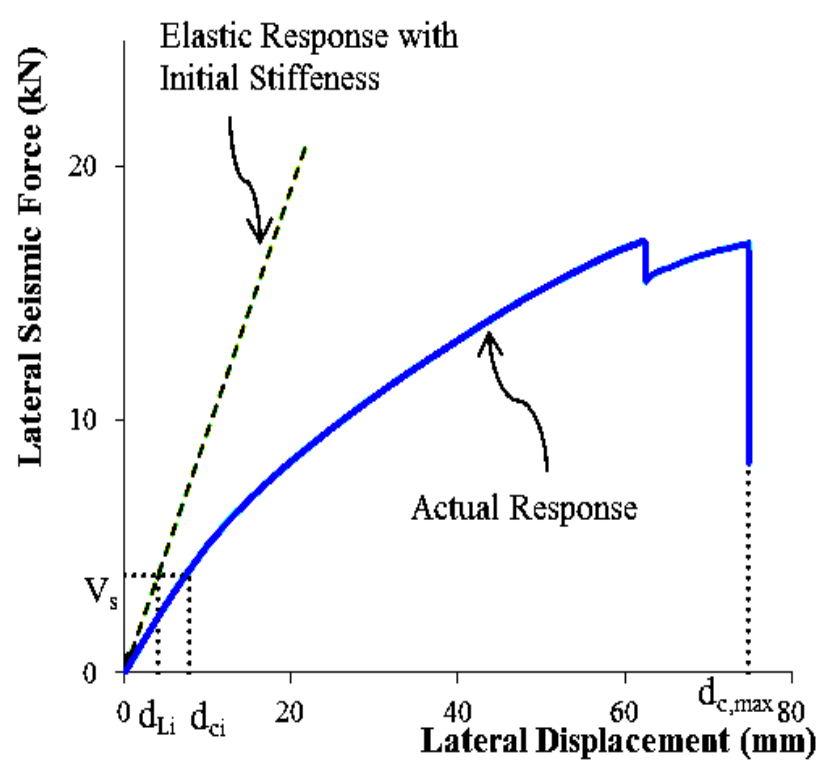

Fig. 12. Calculation of the drifts' deviations of 2-8-43-33-4 Specimen
Table 4. The evaluated response modification factors of 2-h-

\begin{tabular}{|c|c|c|c|c|c|c|c|c|c|c|}
\hline $\begin{array}{l}\text { Specimen } \\
\text { 's name }\end{array}$ & $\begin{array}{c}\Delta \\
y \\
(\mathbf{m} \\
\mathbf{m} \\
)\end{array}$ & $\begin{array}{l}\mathbf{V}_{\mathbf{y}} \\
(\mathbf{k N} \\
/ \mathbf{m})\end{array}$ & $\begin{array}{c}\Delta_{\mathrm{t}} \\
(\mathrm{m} \\
\mathrm{m})\end{array}$ & $\begin{array}{r}\mathbf{V}_{\mathrm{t}} \\
(\mathbf{k N} / \\
\mathbf{m})\end{array}$ & $\begin{array}{c}\mathbf{V}_{\mathbf{s}} \\
(\mathbf{k N} / \\
\mathbf{m})\end{array}$ & $\begin{array}{l}\Omega \\
0\end{array}$ & $\begin{array}{l}\mathbf{R}_{\mathrm{d}} \\
\text { Eq.(4) }\end{array}$ & \begin{tabular}{|l|}
$\mathbf{R}_{\mathrm{d}}$ \\
(Eq. \\
(7))
\end{tabular} & $\mathbf{R}_{1}^{*}$ & $\mathbf{R}_{{ }_{*}{ }^{*}}$ \\
\hline $\begin{array}{l}2-8-43- \\
33-2\end{array}$ & $\begin{array}{r}19 . \\
9 \\
9\end{array}$ & $\begin{array}{l}12 . \\
91\end{array}$ & $\begin{array}{l}67 . \\
72\end{array}$ & $\begin{array}{l}19 . \\
37\end{array}$ & 5.40 & $\begin{array}{r}2.3 \\
9\end{array}$ & $\begin{array}{l}2 . \\
6 \\
4\end{array}$ & $\begin{array}{l}2 . \\
4 \\
0\end{array}$ & $\begin{array}{r}6.3 \\
2\end{array}$ & $\begin{array}{r}5.7 \\
5\end{array}$ \\
\hline $\begin{array}{l}2-9-43- \\
33-2\end{array}$ & $\begin{array}{r}22 . \\
3 \\
5\end{array}$ & $\begin{array}{l}12 . \\
72\end{array}$ & $\begin{array}{l}77 . \\
55\end{array}$ & $\begin{array}{l}17 . \\
81\end{array}$ & 5.31 & $\begin{array}{r}2.4 \\
0\end{array}$ & $\begin{array}{l}2 . \\
6 \\
3\end{array}$ & $\begin{array}{l}2 . \\
4 \\
4\end{array}$ & $\begin{array}{r}6.3 \\
0\end{array}$ & $\begin{array}{r}5.8 \\
4\end{array}$ \\
\hline $\begin{array}{l}2-10-43- \\
33-2\end{array}$ & $\begin{array}{r}20 . \\
3\end{array}$ & $\begin{array}{l}10 . \\
85\end{array}$ & $\begin{array}{l}85 . \\
72\end{array}$ & $\begin{array}{l}18 . \\
30\end{array}$ & 5.15 & $\begin{array}{r}2.1 \\
0\end{array}$ & $\begin{array}{l}3 . \\
1\end{array}$ & & $\begin{array}{r}6.5 \\
3\end{array}$ & $\begin{array}{r}5.7 \\
3\end{array}$ \\
\hline $2-8-43-$ & 27. & 12. & 74. & 16. & 3.85 & 3.1 & 2. & 2. & 7.1 & 6.6 \\
\hline $33-4$ & $\begin{array}{l}0 \\
6\end{array}$ & 11 & 79 & 95 & & 4 & $\begin{array}{l}2 \\
9\end{array}$ & $\begin{array}{l}1 \\
3\end{array}$ & 9 & 9 \\
\hline 2-9-43- & 21. & 9.4 & 80. & 17. & 3.78 & 2.4 & 2. & 2. & 7.3 & 6.3 \\
\hline $33-4$ & $\begin{array}{l}7 \\
5\end{array}$ & 1 & 50 & 01 & & 9 & $\begin{array}{l}9 \\
3\end{array}$ & $\begin{array}{l}5 \\
3\end{array}$ & 0 & 0 \\
\hline $\begin{array}{l}2-10-43- \\
33-4\end{array}$ & $\begin{array}{r}31 . \\
0 \\
8\end{array}$ & $\begin{array}{l}10 . \\
69\end{array}$ & $\begin{array}{l}93 . \\
23\end{array}$ & $\begin{array}{l}15 . \\
51\end{array}$ & 3.50 & $\begin{array}{r}3.0 \\
5\end{array}$ & $\begin{array}{l}2 . \\
4 \\
3\end{array}$ & $\begin{array}{l}2 . \\
2 \\
4\end{array}$ & $\begin{array}{r}7.4 \\
2\end{array}$ & $\begin{array}{r}6.8 \\
3\end{array}$ \\
\hline Average & & & & & & $\begin{array}{r}2.6 \\
0\end{array}$ & $\begin{array}{l}2 . \\
6 \\
7\end{array}$ & $\begin{array}{l}2 . \\
4 \\
1\end{array}$ & $\begin{array}{r}6.8 \\
4\end{array}$ & $\begin{array}{r}6.1 \\
9\end{array}$ \\
\hline $\begin{array}{l}\text { Standard } \\
\text { deviation }\end{array}$ & & & & & & $\begin{array}{r}0.4 \\
1\end{array}$ & $\begin{array}{l}0 . \\
3 \\
0\end{array}$ & $\begin{array}{l}0 . \\
2 \\
1\end{array}$ & $\begin{array}{r}0.5 \\
2\end{array}$ & $\begin{array}{r}0.4 \\
9\end{array}$ \\
\hline
\end{tabular}
43-33-2 and 2-h-43-33-4 specimens.

The material type and the thickness of sheathing have an important effect on the lateral resistance and ductility of the shear wall. However when the pulling out of screws is one of the failure modes of the wall, this effect is lower. This failure mode happened to the walls with screw spacing equal to $15 \mathrm{~cm}$. If the only mode of failure is buckling of the cover sheet, the thickness of the sheet has a determinative effect on the lateral resistance and ductility of the wall.

In table 5 the ultimate loads and R factors of walls for different sheathing thicknesses are compared. Investigating the yielding coordinate of the specimens shows that yielding strength has increased because of the use of the thicker sheet. Overstrength of the frames has a significant increase so that for $2-8-43-t_{2}-2$ and $2-8-43-t_{2}-4$ specimens have a range of 1.86 to 3.27 and 2.66 to 4.13 , respectively. It is noteworthy that the lateral resistance of 2-8-43-27-4 specimen was equal to $15360 \mathrm{~N} / \mathrm{m}$. Coincidentally, the lateral strength of this wall is available in AISI S213-07[2] (2007) is equal to $14594 \mathrm{~N} / \mathrm{m}$. This strength is compared with the result of the finite element analysis. AISI S213$07[2]$ code uses a thinner stud. It is understood that the finite element has a high accuracy.

The screws that connect the sheathing to frame have an essential role in the lateral performance of steel shear walls. These screws carry the lateral load from the frame to the cover sheet, and also act as lateral supports for the studs. They increase the compressive strength of studs by inhibiting their global and distortional buckling. Using adequate number of connection screws will result in decrease in the effective length factor and increase in the strength of the studs significantly. In addition, in the walls with small spacing between screws, pull out of screws does not usually occur so the mode of failure moves towards the 
buckling of cover sheet. Table 6 shows the ultimate load and $\mathrm{R}$ factor of these walls.

Table 5. The evaluated response modification factors of 2-8-43- $\mathrm{t}_{2}-2$ and 2-8-43- $\mathrm{t}_{2}-4$ specimens.

\begin{tabular}{|c|c|c|c|c|c|c|c|c|c|c|}
\hline Specimen's name & $\begin{array}{c}\Delta_{y} \\
(\mathbf{m m})\end{array}$ & $\begin{array}{c}V_{y} \\
(k N / m)\end{array}$ & $\begin{array}{r}\Delta_{t} \\
(\mathbf{m m})\end{array}$ & $\begin{array}{c}\mathbf{V}_{\mathrm{t}} \\
(\mathrm{kN} / \mathrm{m})\end{array}$ & $\begin{array}{c}\mathbf{V}_{\mathrm{s}} \\
(\mathrm{kN} / \mathrm{m})\end{array}$ & $\mathbf{\Omega}_{\mathbf{0}}$ & $\begin{array}{c}\mathbf{R}_{\mathrm{d}} \\
(\mathrm{Eq} .(4))\end{array}$ & $\begin{array}{c}\mathbf{R}_{\mathbf{d}} \\
\text { (Eq.(7)) }\end{array}$ & $\mathbf{R}_{1}$ & $\mathbf{R}_{\mathbf{2}}$ \\
\hline $2-8-43-27-2$ & 14.00 & 9.14 & 54.09 & 15.88 & 4.92 & 1.86 & 2.97 & 2.59 & 5.53 & 4.82 \\
\hline $2-8-43-30-2$ & 16.78 & 10.99 & 60.69 & 17.51 & 5.18 & 2.12 & 2.79 & 2.15 & 5.92 & 7.04 \\
\hline $2-8-43-33-2$ & 19.99 & 12.91 & 67.72 & 19.37 & 5.40 & 2.39 & 2.64 & 2.40 & 6.32 & 5.75 \\
\hline $2-8-43-43-2$ & 31.25 & 18.91 & 87.98 & 24.07 & 5.78 & 3.27 & 2.26 & 2.50 & 7.41 & 5.30 \\
\hline $2-8-43-27-4$ & 22.32 & 9.62 & 80.09 & 15.36 & 3.61 & 2.66 & 2.78 & 2.49 & 7.40 & 6.62 \\
\hline $2-8-43-30-4$ & 21.55 & 9.91 & 74.61 & 16.48 & 3.76 & 2.63 & 2.75 & 2.43 & 7.24 & 6.41 \\
\hline $2-8-43-33-4$ & 27.06 & 12.11 & 74.79 & 16.95 & 3.85 & 3.14 & 2.29 & 2.13 & 7.19 & 6.69 \\
\hline $2-8-43-43-4$ & 37.18 & 16.42 & 92.75 & 22.16 & 3.98 & 4.13 & 2.12 & 2.00 & 8.76 & 8.24 \\
\hline \multirow{2}{*}{\multicolumn{6}{|c|}{$\begin{array}{l}\text { Average } \\
\text { standard deviation }\end{array}$}} & 2.78 & 2.57 & 2.34 & 6.97 & 6.36 \\
\hline & & & & & & 0.72 & 0.31 & 0.21 & 1.02 & 1.07 \\
\hline
\end{tabular}

Table 6. The evaluated response modification factors of 2-8-43-33-s specimens.

\begin{tabular}{|c|c|c|c|c|c|c|c|c|c|c|}
\hline Specimen's name & $\begin{array}{c}\Delta_{\mathrm{y}} \\
(\mathbf{m m})\end{array}$ & $\begin{array}{c}V_{\mathrm{y}} \\
(\mathrm{kN} / \mathrm{m})\end{array}$ & $\begin{array}{c}\Delta_{\mathrm{t}} \\
(\mathbf{m m})\end{array}$ & $\begin{array}{c}V_{t} \\
(k N / m)\end{array}$ & $\begin{array}{c}V_{s} \\
(k N / m)\end{array}$ & $\mathbf{\Omega}_{\mathbf{0}}$ & $\begin{array}{c}\mathbf{R}_{\mathrm{d}} \\
\text { (Eq.(4)) }\end{array}$ & $\begin{array}{c}\mathbf{R}_{\mathrm{d}} \\
\text { (Eq.(7)) }\end{array}$ & $\mathbf{R}_{1}$ & $\mathbf{R}_{2}$ \\
\hline $2-8-43-33-2$ & 19.99 & 12.91 & 67.72 & 19.37 & 5.40 & 2.39 & 2.64 & 2.40 & 6.32 & 5.75 \\
\hline $2-8-43-33-4$ & 27.06 & 12.11 & 74.79 & 16.95 & 3.85 & 3.14 & 2.29 & 2.13 & 7.19 & 6.69 \\
\hline $2-8-43-33-6$ & 17.74 & 7.02 & 64.78 & 14.52 & 3.02 & 2.33 & 3.02 & 2.51 & 7.04 & 5.84 \\
\hline $4-8-43-33-2$ & 11.61 & 14.88 & 33.7 & 21.5 & 6.07 & 2.45 & 2.37 & 2.19 & 5.82 & 5.37 \\
\hline $4-8-43-33-4$ & 11.03 & 9.78 & 36.7 & 19.65 & 4.12 & 2.37 & 2.83 & 2.38 & 6.71 & 5.64 \\
\hline $4-8-43-33-6$ & 9.27 & 6.89 & 31.8 & 15.5 & 2.93 & 2.35 & 2.98 & 2.42 & 7.01 & 5.69 \\
\hline $\begin{array}{l}\text { Average } \\
\text { standard deviation }\end{array}$ & & & & & & $\begin{array}{l}2.51 \\
0.31\end{array}$ & $\begin{array}{l}2.69 \\
0.31\end{array}$ & $\begin{array}{l}2.34 \\
0.15\end{array}$ & $\begin{array}{l}6.68 \\
0.52\end{array}$ & $\begin{array}{l}5.83 \\
0.45\end{array}$ \\
\hline
\end{tabular}

Lateral behavior of cold-formed frames is greatly influenced by the thickness of the tracks and studs. Most of the sections in a cold-formed frame have an open section. The occurrence of local and distortional buckling in these structures is very likely. It is especially important to the frames in which the dominant mode of failure is buckling of the studs and tracks. In this case, the effect of section thickness will be impressive on the lateral strength of the frame.

Table 7 indicates the ultimate loads and $\mathrm{R}$ factors of walls calculated for different section thicknesses. As could be expected, frame section thicknesses has no significant effect on the seismic performance of steel sheet CFS shear wall whose dominant modes of failure are buckling of cover sheet and pull out of connection screws.

Table 7. The evaluated response modification factors of 2-8- $\mathrm{t}_{1}-33-2$ and 2-8- $\mathrm{t}_{1}-33-4$ specimens.

\begin{tabular}{|c|c|c|c|c|c|c|c|c|c|c|}
\hline Specimen's name & $\begin{array}{c}\Delta_{\mathrm{y}} \\
(\mathrm{mm})\end{array}$ & $\begin{array}{c}\mathbf{V}_{\mathbf{y}} \\
(\mathbf{k N})\end{array}$ & $\begin{array}{c}\Delta_{t} \\
(\mathbf{m m})\end{array}$ & $\begin{array}{c}\mathbf{V}_{t} \\
(k N)\end{array}$ & $\mathbf{V}_{\mathrm{s}}$ & $\mathbf{\Omega}_{\mathbf{0}}$ & $\begin{array}{c}\mathbf{R}_{\mathrm{d}} \\
\text { (Eq.(4)) }\end{array}$ & $\begin{array}{c}\mathbf{R}_{\mathrm{d}} \\
\text { (Eq.(7)) }\end{array}$ & $\mathbf{R}_{1}$ & $\mathbf{R}_{2}$ \\
\hline $2-8-33-33-2$ & 30.78 & 14.27 & 77.52 & 15.40 & 4.82 & 2.96 & 2.04 & 2.01 & 6.03 & 5.95 \\
\hline $2-8-43-33-2$ & 19.99 & 12.91 & 67.72 & 19.37 & 5.40 & 2.39 & 2.64 & 2.40 & 6.32 & 5.75 \\
\hline $2-8-53-33-2$ & 22.66 & 15.52 & 71.00 & 20.95 & 5.78 & 2.68 & 2.45 & 2.29 & 6.58 & 6.16 \\
\hline $2-8-33-33-4$ & 20.68 & 8.83 & 72.20 & 14.58 & 3.54 & 2.49 & 2.76 & 2.45 & 6.87 & 6.09 \\
\hline $2-8-43-33-4$ & 27.06 & 12.11 & 74.79 & 16.95 & 3.85 & 3.14 & 2.29 & 2.13 & 7.19 & 6.69 \\
\hline $2-8-53-33-4$ & 23.53 & 11.98 & 73.48 & 18.97 & 4.12 & 2.91 & 2.55 & 2.29 & 7.40 & 6.66 \\
\hline \multirow{2}{*}{\multicolumn{6}{|c|}{$\begin{array}{l}\text { Average } \\
\text { standard deviation }\end{array}$}} & 2.76 & 2.45 & 2.26 & 6.73 & 6.22 \\
\hline & & & & & & 0.29 & 0.26 & 0.16 & 0.52 & 0.38 \\
\hline
\end{tabular}

Sometimes the mechanical properties of steel coldformed sections are essentially different from steel plates, strips, sheets, or bars before forming. During cold-forming the yield point and the average tensile strength increases whereas the ductility decreases. Although, the exact

Investigation of cold work impact on the section's yield strength needs detailed research, it can be simulated by increasing the steel grade instead of average tensile strength increases.
Two series of walls 2-8-43-33-2 and 4-8-43-33-4 were investigated. The yield strengths of the materials are listed in Table 8 .

Table 9 describes the lateral strengths and $\mathrm{R}$ factor of the walls. Comparison of the $\mathrm{R}_{1}$ and $\mathrm{R}_{2}$ factors shows a significant difference among the calculated values that can be attributed to the post yielding slope of the force displacement curves. 
Table 8. Mechanical properties of steel types

\begin{tabular}{c|c|c|c|c}
\hline Type of steel & $\begin{array}{c}\text { Minimum yielding stress } \\
\mathbf{F}_{\mathbf{y}(\mathbf{M P a})}\end{array}$ & $\begin{array}{c}\text { Ultimate stress } \\
\mathbf{F}_{\mathbf{y}(\mathbf{M P a})}\end{array}$ & $\mathbf{F u} / \mathbf{F y}$ & $\begin{array}{c}\text { Minimum kurtosis percentage } \\
\mathbf{( \% )} \text { in } \mathbf{2} \text { inch of length }\end{array}$ \\
\hline Gr. 33 & 227 & 310 & 1.36 & 20 \\
Gr. 37 & 255 & 358 & 1.41 & 18 \\
Gr. 40 & 276 & 379 & 1.38 & 16 \\
Gr. 50 & 345 & 448 & 1.30 & 12 \\
\hline
\end{tabular}

Table 9. The evaluated response modification factors of 2-8-43-33-2-Gr33-50 and 4-8-43-33-4-Gr33-50 specimens.

\begin{tabular}{|c|c|c|c|c|c|c|c|c|c|c|}
\hline Specimen's name & $\Delta_{\mathrm{y}}(\mathrm{mm})$ & $\begin{array}{c}\mathbf{V}_{\mathbf{y}} \\
(\mathrm{kN} / \mathrm{m})\end{array}$ & $\begin{array}{c}\Delta_{\mathrm{t}} \\
(\mathrm{mm})\end{array}$ & $\begin{array}{c}V_{t} \\
(k N / m)\end{array}$ & $\begin{array}{c}\mathbf{V}_{\mathrm{s}} \\
(\mathrm{kN} / \mathrm{m})\end{array}$ & $\mathbf{\Omega}_{\mathbf{0}}$ & $\begin{array}{c}\mathbf{R}_{\mathrm{d}} \\
(\mathbf{E q . ( 4 ) )})\end{array}$ & $\begin{array}{c}\mathbf{R}_{\mathrm{d}} \\
\text { (Eq.(7)) }\end{array}$ & $\mathbf{R}_{1}$ & $\mathbf{R}_{2}$ \\
\hline $2-8-43-33-2-G r 33$ & 19.99 & 12.91 & 67.72 & 19.37 & 5.40 & 2.39 & 2.64 & 2.40 & 6.32 & 5.75 \\
\hline 2-8-43-33-2-Gr37 & 21.47 & 13.92 & 74.95 & 21.75 & 5.45 & 2.56 & 2.72 & 2.45 & 6.94 & 6.25 \\
\hline 2-8-43-33-2-Gr40 & 25.80 & 16.02 & 82.88 & 22.88 & 5.48 & 2.92 & 2.52 & 2.33 & 7.38 & 6.81 \\
\hline $2-8-43-33-2-G r 50$ & 22.18 & 15.02 & 78.77 & 25.79 & 5.55 & 2.71 & 2.82 & 2.47 & 7.63 & 6.69 \\
\hline $2-8-43-33-4-G r 33$ & 27.06 & 12.11 & 74.79 & 16.95 & 3.85 & 3.14 & 2.29 & 2.13 & 7.19 & 6.69 \\
\hline $2-8-43-33-4-g r 40$ & 18.14 & 9.23 & 67.81 & 18.97 & 3.90 & 2.37 & 3.06 & 2.54 & 7.25 & 6.03 \\
\hline $2-8-43-33-4-$ gr50 & 22.47 & 11.23 & 69.83 & 20.00 & 3.93 & 2.86 & 2.62 & 2.28 & 7.49 & 6.53 \\
\hline $2-8-43-33-4-\operatorname{gr} 37$ & 22.46 & 10.85 & 68.61 & 18.05 & 3.88 & 2.80 & 2.54 & 2.26 & 7.12 & 6.33 \\
\hline $\begin{array}{l}\text { Average } \\
\text { standard deviation }\end{array}$ & & & & & & $\begin{array}{l}2.72 \\
0.27\end{array}$ & $\begin{array}{l}2.65 \\
0.23 \\
\end{array}$ & $\begin{array}{l}2.36 \\
0.13 \\
\end{array}$ & $\begin{array}{l}7.16 \\
0.40 \\
\end{array}$ & $\begin{array}{l}6.38 \\
0.36 \\
\end{array}$ \\
\hline
\end{tabular}

\section{Strengthening of Walls with Changing Screws Configuration}

In walls with screws spacing equal to $15 \mathrm{~cm}$ (6 inches), the type of failure that diminishes the loading capacity of the shear wall panel is the pull out of screws that connect the sheathing to the frame. If the pull out of the screws are avoided by a method, it will be feasible to utilize the full capacity of the sheet cover. Although pull out of the screws generally takes place in the corners of the shear wall at the side of load application, the walls should be strengthened at all corners because of cyclic nature of earthquake. One method for strengthening the wall is to put extra screws at the four corners of the wall. Three configurations are considered for reinforcing screws as described below:

Configuration 1: using three extra screws in two corners of the studs (addition screws with number of 1,2, and 3 in Fig. 13a)

Configuration 2: Using five extra screws in two corners of the studs (addition screws with number of 1-5 in Fig. 13b).

Configuration 3: Using both five extra screws in two corners of the studs and screws with center to center spacing of 2 inches in the tracks (addition screws with number of 111 in Fig. 13c).

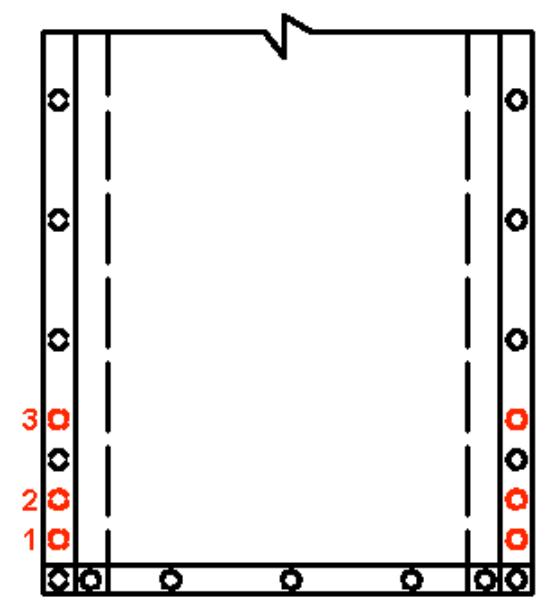

(a)

Fig. 13. Arrangement of the reinforcing screws

In the first method that only 12 extra screws have been used, the wall had a $21 \%$ growth in lateral resistance. According to method 2, using 20 extra screws resulted in growth of $18 \%$ in lateral strength of the wall. Comparison of two methods shows a lower lateral resistance of the shear wall with more reinforcing screws. To elucidate the reason of the phenomenon, the type of failure was considered in

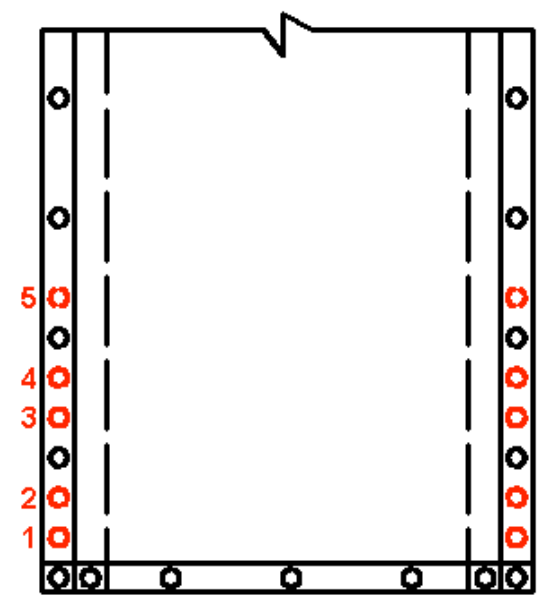

(b)

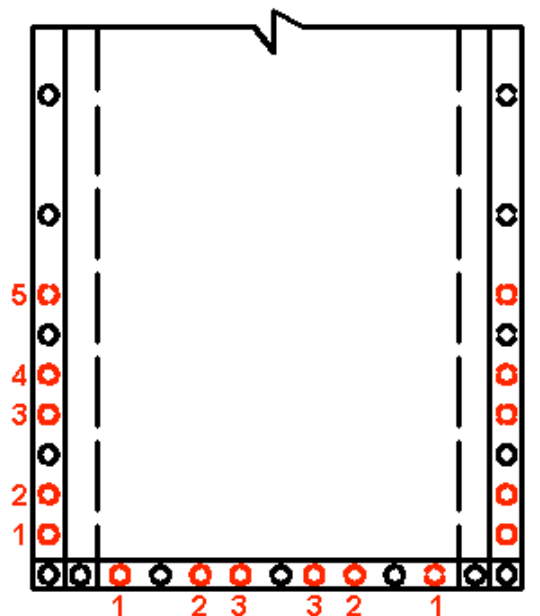

(c)

both configurations. Investigation of failure mode of the wall with first configuration shows that buckling of the cover sheet has occurred with more waves. So, less force is exerted to each screw. Distortional buckling of the corner stud was major mode of failure. In the second method, the higher number of screws inhibited stud failure; thus only one wave of buckling forms in cover sheet which passes through the track. Because of the screws that connect the cover sheet to 
the track was weak, buckling wave delivered a greater force to these screws. Thus, the screws experience the pull out failure at the position of the track. To improve this method, third method was developed. The Increasing of lateral resistance of the wall was equal to $25 \%$.

Table 10 indicates the lateral strength and $\mathrm{R}$ factor of 2 8-43-33-6 specimen with the influence of the presence of extra screws in form of three configurations. It may be seen that in all three methods, especially in method one and three, the respective displacement at the point of maximum load is also increased and this leads to an increase in the ductility of the frame.

\section{Discussion and Comparison}

Recent prescribed value of $\mathrm{R}$ factor by standard codes including IBC[30], FEMA 450[31], ASCE07-10[1] is a number of 6.5 for steel sheathed cold-formed steel walls. The $\mathrm{R}$ factor calculated in this research indicates that if the effect of post yielding strength is not considered, response modification factors for steel sheathed cold-formed steel systems will range between 4.8 and 8.2 and the average of them is 6.35 with standard deviation of 0.67 . Therefore, $57 \%$ of evaluated $\mathrm{R}$ factors are less than the prescribed value for steel sheathed cold-formed steel walls in the design codes. It is because the post yielding strength capacity was ignored and the running process was stopped due to convergence problem in most specimens. More explain on later reason is that despite the fact that most specimens were able to experience more displacement range without significant strength reduction, the running process has been stopped owing to convergence problem.

Table 10. The evaluated response modification factors of 2-8-43-33-6 with three method of screws arrangement.

\begin{tabular}{|c|c|c|c|c|c|c|c|c|c|c|}
\hline Specimen's name & $\begin{array}{c}\Delta_{y} \\
(\mathbf{m m})\end{array}$ & $\begin{array}{c}\mathbf{V}_{\mathbf{y}} \\
(\mathbf{k N} / \mathbf{m})\end{array}$ & $\begin{array}{c}\Delta_{\mathrm{t}} \\
(\mathrm{mm})\end{array}$ & $\begin{array}{c}\mathrm{V}_{\mathrm{t}} \\
(\mathrm{kN} / \mathrm{m})\end{array}$ & $\begin{array}{c}\mathbf{V}_{\mathrm{s}} \\
(\mathrm{kN} / \mathrm{m})\end{array}$ & $\mathbf{\Omega}_{\mathbf{0}}$ & $\begin{array}{c}\mathbf{R}_{\mathrm{d}} \\
\text { (Eq.(4)) }\end{array}$ & $\begin{array}{c}\mathbf{R}_{\mathrm{d}} \\
\text { (Eq.(7)) }\end{array}$ & $\mathbf{R}_{1}$ & $\mathbf{R}_{2}$ \\
\hline $2-8-43-33-6$ & 17.74 & 7.02 & 64.78 & 14.52 & 3.02 & 2.33 & 3.02 & 2.51 & 7.04 & 5.84 \\
\hline $2-8-43-33-6-01^{*}$ & 20.30 & 8.86 & 81.21 & 18.27 & 3.50 & 2.53 & 3.19 & 2.65 & 8.08 & 6.70 \\
\hline $2-8-43-33-6-02$ & 19.41 & 9.25 & 70.52 & 17.69 & 3.81 & 2.43 & 2.94 & 2.50 & 7.14 & 6.07 \\
\hline $2-8-43-33-6-03$ & 36.89 & 15.66 & 87.04 & 18.75 & 4.10 & 3.82 & 2.00 & 1.93 & 7.62 & 7.36 \\
\hline $\begin{array}{l}\text { Average } \\
\text { standard deviation }\end{array}$ & & & & & & $\begin{array}{l}2.77 \\
0.70\end{array}$ & $\begin{array}{l}2.79 \\
0.54\end{array}$ & $\begin{array}{l}2.40 \\
0.32\end{array}$ & $\begin{array}{l}7.47 \\
0.48\end{array}$ & $\begin{array}{l}6.49 \\
0.68\end{array}$ \\
\hline
\end{tabular}

* 2-8-43-33-6-01 defines as 2-8-43-33-6 specimen with extra screws arrangement as configuration1

Ignoring the second stiffness of the curves leads to the part of the structure capacity not being considered in the energy dissipation. Thus, it is reasonable that the direct calculation of $R_{d}$ using Eq. (2) is considered as the basis for calculating $\mathrm{R}$ factor. By this assumption, the response modification factors for steel sheathed cold-formed steel systems would range between 5.53 and 8.76 and the average of them is 7.07 with standard deviation of 0.69 . Fig. 14 shows the calculated values of ductility reduction factor and $\mathrm{R}$ factor using two described method, schematically.

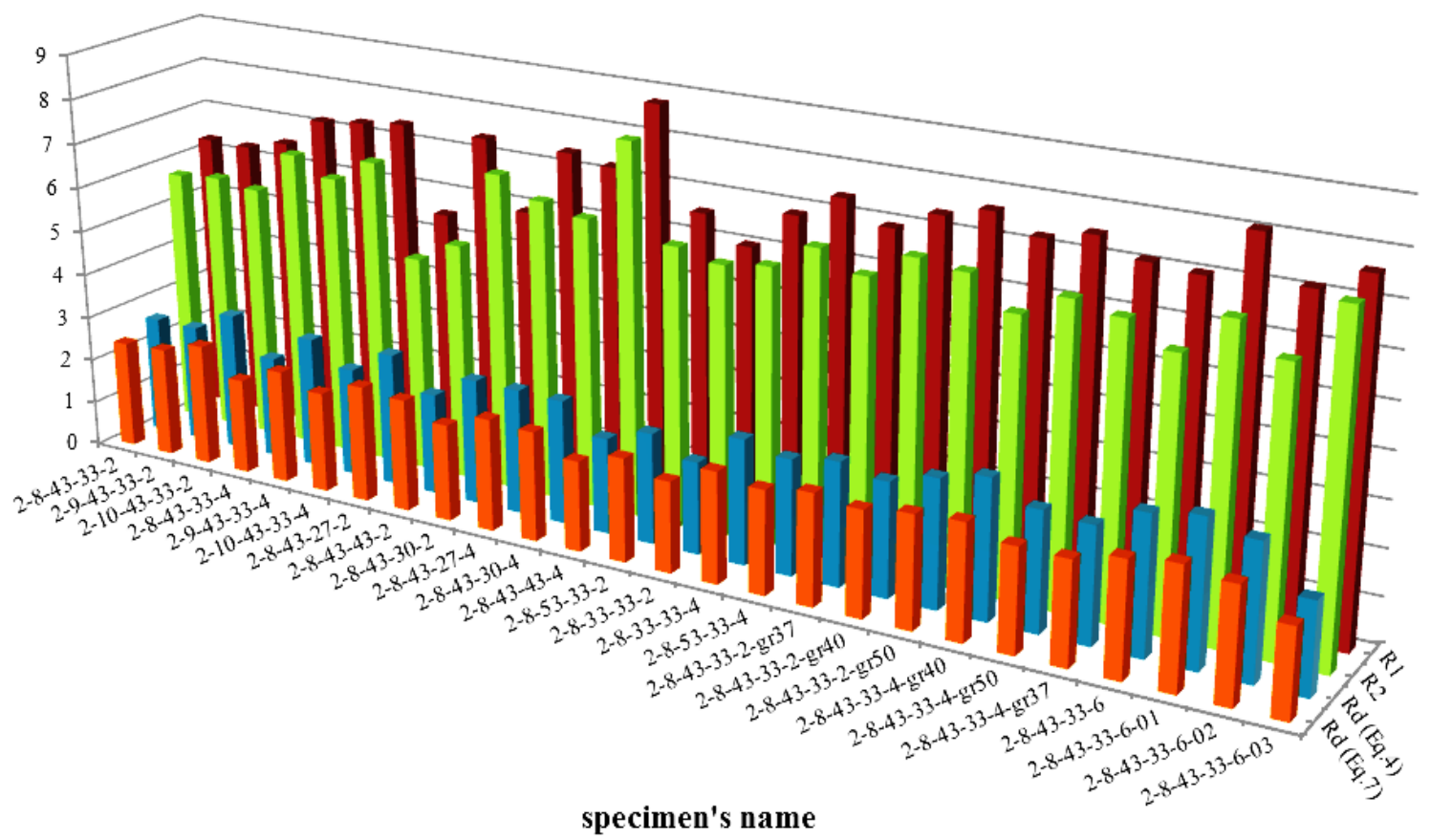

Fig. 14 Ductility reduction factor and response modification factor

\section{Conclusions}

In this study the behavior of steel shear walls in cold-formed structures and their response modification factors were investigated with the finite element pushover analysis with ABAQUS software. The model takes into account the nonlinear behavior of the materials, initial defects of the cover sheet, post buckling strength of steel sections and 
failure mode of the screws that connect the cover sheet to frame.

In order to verify the model, the results of the finite element analysis were compared to 10 experimental shear wall panel specimens. The accuracy and precision of the finite element method was confirmed, and then parametric studies were conducted which yield the following results:

1- Connection of the cover sheet to frame and its modes of failure are indicated in the models which yield to knowing the great influence on the accuracy of the finite element model and the precision of the results. The connection screws were substituted with elastic links that simulate the displacements of the point of connection. This was found to be practical in modeling the connection and understanding the lateral behavior of the wall.

2- The spacing of screws that connect the cover sheet to frame sections is very important and greatly affects the lateral strength and failure mechanism of the wall. By increasing screws' space, the prevailing mode of failure moves towards pulling out of screws. On the other hand, by lowering spaces, sheet buckling and distortion of the corner stud will control the lateral strength of the wall.

3- Increasing the shear wall height makes a distinct decrease in stiffness and lateral strength of wall.

4- The thickness of the cover sheet has an important effect on the stiffness and ultimate lateral strength of shear wall panels. With wider walls however, this adverse effect on the lateral strength diminishes. For example, the increase in lateral strength due to increasing the thickness is more in walls with width equal to $0.61 \mathrm{~m}$ than walls with width equal to $1.22 \mathrm{~m}$.

5- Increasing the yield strength of the sheathing plays a major role in initial stiffness and ultimate lateral strength of the system.

6- The use of extra screws at the critical points in walls with screw spacing equal to $15 \mathrm{~cm}$ (the screws that connect the cover sheet to the frame) contributes to increasing the lateral strength. By adding only 12 screws in the corners, the lateral strength of the wall may increase by 21 percent. The lateral strength of shear wall with reinforced screw spacing of $15 \mathrm{~cm}$ is 7 percent more than the strength of a wall with screw spacing of $10 \mathrm{~cm}$.

7- Comparing the prescribed $\mathrm{R}$ factors for steel sheathed cold-formed steel walls $(\mathrm{R}=6.5)$ with evaluated $\mathrm{R}$ factor in this research shows that codes value is reasonable. Also, in order to reach the desire performance of steel sheathed cold-formed steel walls, it is beneficial to utilize the post yielding strength capacity.

This is an Open Access article distributed under the terms of the Creative Commons Attribution Licence

\section{References}

1. ASCE07-10, Minimum design loads for buildings and other structures, American Society of Civil Engineers, (2010).

2. AISI S213-07, Standard for cold-formed steel framing Lateral design, American Iron and Steel Institute (2007).

3. AISI S240-15, North American Standard for Cold-Formed Steel Structural Framing, American Iron and Steel Institute (2015).

4. AISI S400-15, North American Standard for Seismic Design of ColdFormed Steel Structural Systems, American Iron and Steel Institute (2015).

5. E.F. Gad, C.F. Duffield, G.L. Hutchinson, D.S. Mansell, G. Stark, Engineering Structures. 21, 83 (1999).

6. L.A. Fulop, D. Dubina, Thin- Walled Structures. 42, 321 (2004).

7. Y.S. Tian, J. Wang, T.J. Lu, Journal of Constructional Steel Research. 60, 1069 (2004).

8. R. Serrette, K. Ogunfunmi, Journal of Structural Engineering, 122, 383 (1996).

9. T.W. Kim, J. Wilcoski, D.A. Foutch, M.S. Lee, Engineering Structures. 28, 1462 (2006).

10. C. Yu, Report No. UNT-G76234, University of North Texas (2007).

11. M. Al-Kharat, C.A. Rogers, Journal of Constructional Steel Research. 63, 460 (2007).

12. S. Hatami, H.R Ronagh, M. Azhari, Fifth International Conference on Thin-Walled Structures. Brisbane, (2008).

13. H. Zeynalian, H.R. Ronagh, Thin Walled Structures. 51, 64 (2012).

14. P. Liu, K.D. Peterman, B.W. Schafer, Journal of Constructional Steel Research. 101, 114 (2014).

15. M.R. Javaheri-Tafti, H.R. Ronagh, F. Behnamfar, P. Memarzadeh, Thin-Walled Structures. 80, 66 (2014).

16. S. Mohebbi, R. Mirghaderi, F. Farahbod, A. Bagheri Sabbagh, ThinWalled Structures. 91, 50 (2015).

17. M. Zeynalian, H.R. Ronagh, Journal of Constructional Steel Research. 107, 1 (2015).

18. R.L. Serrette, Report No. LGSRG-1-97, Santa Clara University (1997).

19. R.L. Serrette, Final Report: LGSRG-06-02, Santa Clara University (2002).

20. C. Yu, Y. Chen, Report No. UNT-G70752, University of North Texas (2009).

21. J. Dabreo, N. Balh, C. Ong-Tone, C.A. Rogers, Thin-Walled Structures. 74, 232 (2014).
22. N.Balh, Dabreo, J. Ong-Tone, C. El-Saloussy, K. Yu, C.A. Rogers, Thin-Walled Structures. 75, 76 (2014).

23. N. Yanagi, C. Yu, Journal of Structural Engineering. 140, 1013 (2014).

24. A. Shakibanasab, N. K. Attari, M. Salari, Thin-Walled Structures. 77, 56 (2014).

25. C. Blais, M.S. thesis, McGill University (2006).

26. D. Rokas, M.S. thesis, McGill University (2006).

27. F.A. Boudreault, M.S. Thesis, McGill University (2005).

28. F.A. Boudreault, C. Blais, C.A. Rogers, Can J CivEng. 3, 56 (2007).

29. UBC, Uniform Building Code, CA, (1997).

30. IBC, International Building Code, Country Club Hills, (2003).

31. FEMA 450, NEHRP recommended provision for seismic regulations for new buildings and other structures, Washington, (2003).

32. NBCC, National Building Code of Canada, Ottawa, (2005).

33. ATC-3-06, Tentative provisions for the development of seismic regulations for buildings, USA, (1978).

34. ASCE 41-13, Seismic Evaluation and Retrofit of Existing Buildings, USA, (2013).

35. ATC 40, Methodology for Evaluation and Upgrade of Reinforced Concrete Buildings, California, (1996).

36. R. Park, Bull N Z NatlSoc Earthquake Eng. 22, 155 (1989).

37. ASTM A1003, Standard specification for sheet steel, carbon, metallic and non-metallic coating for cold-formed framing members, (2008).

38. SSMA, SSMA Product technical information ICBO ER-4943P. Glen Ellyn (IL): Steel Stud Manufacturers Association, (2001).

39. C. Yu, Journal of Engineering Structures. 32, 1522 (2008).

40. C. Yu, Y. Chen, Journal of Constructional Steel Research. 67, 93 (2010).

41. B.W. Schafer, T. Pekoz, Journal of Constructional Steel Research. 47, 193 (1998)

R.L. Serrette, H. Nguyen, G. Hall, Report No. LGSRG-3-96, Santa Clara University (1996).

42. M. Zeynalian, H.R. Ronagh, S. Hatami, Journal of Constructional Steel Research. 77, 23 (2012).

43. N. Newmark, W. Hall, Earthquake Spectra and Design. (1982). 